\author{
M. ISHAQ NADIRI* \\ New York University
}

and the National Bureau of Economic Research

\title{
An Alternative Model of Business Investment Spending
}

Despite a VAST Literature on THe Determinants of investment behavior, questions about the way in which relative prices and output influence investment expenditures have not been satisfactorily resolved. In the "neoclassical" investment models, relative prices and output are commonly introduced as a composite variable, a procedure that does not allow for the possibility of separate and distinct effects of these two determinants on the level of investment expenditures. ${ }^{1}$ Yet separation of these effects is critical

* I am indebted to members of the Brookings panel for their important and considerate comments. I have benefited greatly from the competent assistance of Edward Matluck and Veena Gupta; I am grateful to Rose Ferro and Laura Chasen for their efficient secretarial help.

1. The neoclassical specification follows from the assumption about the form of the underlying production function. If the production function is considered to be CobbDouglas, the elasticity of investment with respect to relative prices and output is, by assumption, unity. If the production function is constant elasticity of substitution, and a vintage model of capital is assumed, the pattern of responses of investment to price changes and to output changes will differ. See Charles W. Bischoff, "The Effect of Alternative Lag Distributions," in Gary Fromm (ed.), Tax Incentives and Capital Spending (Brookings Institution, 1971), pp. 61-125. For a survey of the empirical performance of several econometric investment models, see Charles W. Bischoff, "Business Investment in the 1970s: A Comparison of Models," Brookings Papers on Economic Activity (1: 1971), pp. 13-58. Intermingling of rental prices and output is also defended on the grounds that the data on rental prices are subject to substantial errors of measurement. See Arnold Harberger's discussion in Tax Incentives, pp. 256-62. This argument is spurious, for if the price component of the synthesized variable is subject to measurement errors of unknown magnitude, the resulting estimates of the investment equations are certainly unreliable. 
for designing effective monetary and fiscal policies to stabilize and stimulate the growth of the economy.

In this paper the importance of separating price and output effects is examined within the framework of explaining gross investment expenditures on plant and equipment in the post-Korean war period. The investment series analyzed is total private nonfarm expenditures on plant and equipment - the category all industries-reported in the surveys of capital expenditures conducted by the Office of Business Economics and the Securities and Exchange Commission. ${ }^{2}$

The analysis is based on a disequilibrium model that interrelates in a unified framework the demands for labor and capital, the two factors of production considered here, and their rates of utilization. In the first section, the salient features of the model are described briefly in order to show the linkages between decisions on investment and those on employment of labor and the utilization rates of labor and capital, and to indicate the response of aggregate investment to changes in output and in relative input prices.

The second section of the paper uses one equation of the interrelated factor demand model, the capital stock equation, to analyze the short-run behavior of aggregate investment. The contributions of relative prices, output, and disequilibrium in other inputs to the explanation of investment behavior are exhibited and briefly discussed. The results obtained from the model are compared with those of the conventional standard neoclassical model of investment behavior. The effects of monetary and fiscal policies on investment expenditures are discussed briefly; and conditional and dynamic forecasts of investment expenditures for the period outside the sample are presented.

\section{The Investment Process}

The analysis of investment spending can be divided into two stages: (1) determining the equilibrium level of capital stock, and (2) determining the adjustment process by which investment expenditures bring capital

2. The OBE-SEC series on plant and equipment expenditures for all industries moves in a manner similar to that of the series on nonfarm nonresidential fixed investment in the national income and product accounts. The percentage difference between these two series remains fairly constant. For comparison of the two, see Survey of Current Business, Vol. 50 (January 1970), pp. 26-27. 
stock to this level, allowing for delays in raising and appropriating funds, placing orders, and adapting the existing capital stock and other inputs to accommodate the new capital. In the model sketched below, the desired capital stock is determined by expected relative input prices (the real wage rate and the rental price of capital services), and expected output. The demand for other inputs is treated in a symmetrical way. The adjustment process is conceived as a feedback system in which the disequilibrium in one input affects the speed of adjustment of others. The resulting model of factor demands includes most of the existing econometric models of investment and employment as special cases.

\section{THE DESIRED LEVEL OF INPUTS}

Consider a firm that minimizes its total cost subject to a Cobb-Douglas production function. The objective function to be minimized can be stated as

$$
M=W L H+S L+P_{k}(r+\delta) K-\lambda[X-F(.)],
$$

where

$$
X=F(.)=A L^{\alpha_{1}} H^{\alpha_{2}} K^{\alpha_{3}} U^{\alpha_{4}}
$$

and

$$
\begin{aligned}
X & =\text { output } \\
L & =\text { the stock of labor } \\
K & =\text { the stock of capital } \\
H & =\text { hours worked } \\
U & =\text { the utilization rate of capital } \\
A & =\text { a constant } \\
W & =\text { the hourly wage rate } \\
S & =\text { the rental price of labor }{ }^{3} \\
P_{k} & =\text { the purchase price of capital } \\
r & =\text { the cost of capital } \\
\delta & =\text { the depreciation rate of capital stock, which is assumed to } \\
& \quad \text { depend on the utilization rate of capital and time; that is, } \\
\quad \delta=\delta(U, t) & \\
P_{k}(r+\delta) & =\text { the rental price of capital services } \\
\lambda & =\text { the Lagrange multiplier. }
\end{aligned}
$$

3. In principle, $S$ should include some fringe benefits, retraining costs, and the like. 
Capital, employees, and the utilization of capital and of employees (measured by average hours worked) are all considered inputs to production in the present model. Solutions of equations (1) and (2) for the desired levels of capital and employment depend on expected output and relative prices, while the equilibrium level of hours and the utilization rates of capital depend on relative prices alone. The solutions are

$$
\begin{aligned}
L^{*} & =(X)^{1 / \rho}\left(\frac{W}{C}\right)^{\alpha_{2} / \rho}\left(\frac{C}{S}\right)^{\left(\alpha_{3}+\alpha_{2}\right) / \rho}\left[(r+\delta) / \delta^{\prime}\right]^{-\alpha_{4} / \rho} \\
H^{*} & =\left(\frac{S}{W}\right)\left[(1+\epsilon)\left(1-\frac{\alpha_{1}}{\alpha_{2}}\right)\right] \\
K^{*} & =(X)^{1 / \rho}\left(\frac{W}{C}\right)^{\alpha_{1} / \rho}\left(\frac{S}{W}\right)^{\left(\alpha_{1}-\alpha_{2}\right) / \rho}\left[(r+\delta) / \delta^{\prime}\right]^{\alpha_{4} / \rho} \\
U^{*} & =\left[(r+\delta) / \delta^{\prime}\right]^{\alpha_{4} / \alpha_{3}},
\end{aligned}
$$

where $C$ is $P_{k}(r+\delta)$, the rental price of capital services, $\delta^{\prime}$ is the derivative of $\delta$ with respect to the utilization rate $U, \epsilon$ is the elasticity of hours worked with respect to the hourly wage rate, and $\rho=\alpha_{1}+\alpha_{3}$ is the returns-to-scale parameter. Note that the exponents of the relative prices depend on the production function parameters. The relevant measures for output and prices are their expected values. The specification of such variables and the manner in which they enter the above equations depend on the underlying expectation processes and are discussed below.

\section{THE ADJUSTMENT PROCESS}

Adjustment of an input to its desired level entails costs that generally increase with the speed of adjustment of both the particular input itself and all other inputs. For example, in response to an increase in demand or price, the firm may initially use existing labor and capital more intensively and thus incur overtime wage payments and higher maintenance costs. When the change in demand is expected to be permanent, the firm will hire new employees and invest in new capital goods. Doing so entails certain adjustment "costs" due to the hiring and training of new employees, ordering new capital, and the inability to recover all production costs of existing capital through resale. These costs will be higher if the planning periodand thus the amortization period-is very short.

These costs are interrelated. Sluggish adjustment of capital stock will moderate the increase in employment while excess capacity will encourage 
it. Similarly, capital stock adjustments will be hampered in the short run if qualified workers are not already at work in the firm or readily available elsewhere. Recall that the disequilibrium in other inputs affects only the adjustment rate and not the desired level of an input. The latter is determined by expected output and relative prices, according to (3).

The generalized adjustment model for the four decision variables can be written as

$$
\left(\frac{Y_{i_{t}}}{Y_{i_{t-1}}}\right)=\prod_{j=1}^{4}\left(\frac{Y_{j_{t}}^{*}}{Y_{j_{t-1}}}\right)^{\beta_{i j}}, \quad \beta_{i j}\left\{\begin{array}{l}
\geq 0 \text { if } i=j \\
\sum_{0} \text { if } i \neq j
\end{array},\right.
$$

where $Y_{i}(i=1, \ldots 4)$ are the four inputs, $K, L, H$, and $U$, respectively; $Y^{*}$ represents the equilibrium long-run values of the inputs determined according to the decision rule (3); $\beta_{i j}$ is the matrix of the constant adjustment coefficients; and $\Pi$ indicates that the product of the four terms is to be taken. Thus each adjustment cost is assumed to be proportional to the difference between the actual and equilibrium values of the input.

\section{THE STRUCTURAL EQUATIONS}

Substituting the desired values of inputs from equation (3) into equation (4) and taking logarithms of both sides of the resulting equations yields the following "structural" equations for the adjustment of the four inputs:

$$
\begin{aligned}
l_{t}= & a_{1}+\left(1-\beta_{11}\right) l_{t-1}-\beta_{12} k_{t-1}-\beta_{13} h_{t-1}-\beta_{14} u_{t-1} \\
& +\gamma_{15} x_{t}^{e}+\gamma_{16}\left(\frac{w}{c}\right)_{t}^{e}+\gamma_{17} T+\epsilon_{1 t} \\
k_{t}= & a_{2}-\beta_{21} l_{t-1}+\left(1-\beta_{22}\right) k_{t-1}-\beta_{23} h_{t-1}-\beta_{24} u_{t-1} \\
& +\gamma_{25} x_{t}^{e}+\gamma_{26}\left(\frac{w}{c}\right)_{t}^{e}+\gamma_{27} T+\epsilon_{2 t} \\
h_{t}= & a_{3}-\beta_{31} l_{t-1}-\beta_{32} k_{t-1}+\left(1-\beta_{33}\right) h_{t-1}-\beta_{34} u_{t-1} \\
& +\gamma_{35} x_{t}^{e}+\gamma_{36}\left(\frac{w}{c}\right)_{t}^{e}+\gamma_{37} T+\epsilon_{3 t} \\
u_{t}= & a_{4}-\beta_{41} l_{t-1}-\beta_{42} k_{t-1}-\beta_{43} h_{t-1}+\left(1-\beta_{44}\right) u_{t-1} \\
& +\gamma_{45} x_{t}^{e}+\gamma_{46}\left(\frac{w}{c}\right)_{t}^{e}+\gamma_{47} T+\epsilon_{4 t} .
\end{aligned}
$$

All the lower-case letters for inputs refer to logarithms of the original variables designated by capital letters; the superscript $e$ on the output- $x^{e}-$ 
and relative price- $(w / c)^{e}$-terms indicate the expected values of these variables, ${ }^{4}$ and $\epsilon_{i}(i=1, \ldots 4)$ is the stochastic error term with zero mean and constant variance. The feedback effects are captured by the lagged dependent variables in each equation; the matrix of $\beta \mathrm{s}\left(\beta_{i j}\right)$ expresses the total feedback among the inputs. The signs of the cross-adjustment coefficients $\left(\beta_{i j}\right.$ where $\left.i \neq j\right)$ can be interpreted in terms of "dynamic" substitution or complementarity. This concept differs from the conventional meaning of the terms, which are equilibrium concepts. In a dynamic setting, the shortterm adjustment costs may lead firms temporarily to substitute one factor for another even though they are complements in the long run.

Several features of the decision process depicted by (5) should be noted. First, the adjustment process is very general. It allows for inputs to overshoot their equilibrium values in the short run. The process reduces to the familiar capital stock adjustment models if the spillovers from other inputs are nonexistent $\left(\beta_{i j}=0\right.$ for $\left.i \neq j\right)$.

Second, some elements of the adjustment matrix $\left(\beta_{i j}\right)$ may be zero; that is, the feedback system may not be a complete loop. It is possible that disequilibrium in one input-say, capital stock-will affect decisions about others, while that input itself is immune to the disequilibria in others. The market and technical conditions of an industry will determine the nature and extent of the feedbacks among the inputs.

Third, the "own" adjustment of a dependent variable $\left[\left(1-\beta_{i j}\right), i=j\right]$ is necessarily positive, while the adjustment effects of disequilibria from other inputs could be positive, negative, or zero. If $\beta_{i j}$ is positive, a shortage in input $j$ increases the short-run demand for factor $i$ and consequently $i$ and $j$ are "dynamic" substitutes. If $\beta_{i j}$ is negative, the inputs are "dynamic" complements in the short run.

Fourth, the price and output coefficients $\left(\gamma_{i j}, i=1, \ldots 4 ; j=5,6\right)$ consist of the long-run output elasticities $\left(\alpha_{i}\right)$ modified by the adjustment coefficients $\left(\beta_{i j}\right)$; thus they represent the short-run effects of output and price changes on input demand. The initial effects of either output or prices in a particular equation of system (5)-say, investment expenditures-may be zero. However, so long as the output and relative price variables are significant in any other equation of (5), they will affect investment behavior from the second period on; their effects are transmitted through the feedback among inputs.

4. All the relative prices in (3) are collapsed into one variable $(w / c)$. The omission of other relative prices, necessitated by lack of the appropriate data, biases the coefficients of the regression equations reported below. 
Fifth, to calculate the distributed lag response of the inputs to changes in relative prices and output, and to obtain the long-run effects of output and prices on investment and employment, requires the reduced-form solution of the structural equation system (5).

Sixth, any of the structural equations can be used for estimating and forecasting the short-run behavior of the relevant dependent variable. I use the second equation of (5) to predict net investment at the aggregate level.

\section{Estimation of the Model for All Industries}

The structural equations (5) are estimated using data for all industries for the sample period 1953:1 through 1969:4. The results are reported below. The nature of the data and methods of constructing the variables are described briefly here and more completely in Appendix B. Also, some of the specification problems are discussed before the estimates of the structural equations are presented.

\section{THE NATURE OF THE DATA}

Estimating the equation system (5) requires consistent data on wages, user cost of capital, output, capital stock, employment, hours worked, and capital utilization. Some of these data are readily available but others had to be constructed. The capital stock series $(K)$ is generated by the perpetual inventory method using seasonally adjusted and deflated investment series reported in the Survey of Current Business. The benchmark is taken from Hickman $^{5}$ and the depreciation rate from Hall and Jorgenson. ${ }^{6}$ The appropriate measure of the utilization rate $(U)$ is an index of "hours per machine," but since it is not available, the Wharton School index of capacity utilization is used as a proxy. ${ }^{7}$ This is basically an inadequate measure of capital utilization and should be considered only a proxy variable. Employment $(L)$ is measured by the total number of employees in the nonfarm business sector, and $(H)$ refers to hours worked by production workers. The output

5. Bert G. Hickman, Investment Demand and U.S. Economic Growth (Brookings Institution, 1965), p. 230.

6. Robert E. Hall and Dale W. Jorgenson, "Application of the Theory of Optimum Capital Accumulation," in Fromm (ed.), Tax Incentives, pp. 9-60.

7. The methodology of the index is explained in L. R. Klein and R. S. Preston, "Some New Results in the Measurement of Capacity Utilization," American Economic Review, Vol. 57 (March 1967), pp. 34-58. 
variable $(X)$ is measured by quarterly real income originated for all industries.

The wage rate $(W)$ is measured by the hourly wage rate of production workers in the manufacturing sector. The rental price of capital services $(C)$ is a composite variable, taking account of the purchase price of capital, interest rates, liberalization of depreciation guidelines, changes in average age of capital, and the investment tax credit. Its form is

$$
C=\frac{P_{k}(\bar{r}+\delta)\left(1-\bar{k}-v z+v z k^{\prime}\right)}{(1-v)},
$$

where

$$
\begin{aligned}
& P_{k}=\text { the purchase price index of capital goods } \\
& \vec{r}=\text { the quarterly real rate of interest, and is equal to } r-(\dot{p} / p)^{e} \text {, where } \\
& \quad r \text { is the nominal long-term interest rate and }(\dot{p} / p)^{e} \text { is a measure of } \\
& \quad \text { expected price change } 8
\end{aligned}
$$

8. The weights derived by Gordon were used to construct a measure of expected price changes. The actual weights are the first thirteen coefficients shown in Robert J. Gordon, "Inflation in Recession and Recovery," Brookings Papers on Economic Activity (1:1971), Column 6, Table A-1, p. 148. They are: 0.045, 0.050, 0.054, 0.055, 0.055, 0.053, 0.050, $0.047,0.042,0.038,0.033,0.028$, and 0.024 .

Another method for adjusting the cost of capital for changes in the price level is to use the "threshold weights" suggested by Albert Ando, Franco Modigliani, Robert Rasche, and Stephen Turnovsky, in their paper "On the Role of Expectations of Price Changes and Technological Change in an Investment Function" (March 1971; processed). The basic criterion is that the rate of price increase should exceed a critical value and become large enough to affect substantially the cost of capital. Although this is a worthwhile suggestion, I have not followed this procedure: The weights could not be estimated as part of the estimation of the investment equation because doing so introduces severe nonlinearities. Even obtaining the weights or imposing them may not be a good proxy of the ex ante expectation and may not be any better than the weights used.

In several studies, the price-earnings ratio of publicly traded common stock is included in the measure of cost of capital, $r$. I have not made this adjustment in the rental price of capital services, $c_{1}$ and $c_{2}$, because the price-earnings ratio is basically an expectational variable that affects the rate of return and is not part of the cost of capital. See Robert Eisner and M. I. Nadiri, "Investment Behavior and Neo-classical Theory," Review of Economics and Statistics, Vol. 50 (August 1968), pp. 369-82. Moreover, in most of the postwar period, equity financing as a ratio of capital expenditure has been fairly small in the nonfarm nonfinancial corporate sector and the volume of equity financing has shown little correlation with the price-earnings ratio. See Joel Popkin, "A Study of the Determinants of Both Plant and Equipment Expenditures," Staff Working Paper in Economics and Statistics 13 (U.S. Office of Business Economics, March 1967; processed), p. 14; and Robert W. Resek, "Investment by Manufacturing Firms: A Quarterly Time Series Analysis of Industry Data," Review of Economics and Statistics, Vol. 48 (August 1966), pp. 322-33. 
$\delta=$ the quarterly depreciation rate

$\bar{k}=$ the effective rate of investment tax credit

$v=$ the corporate income tax rate

$z=$ the present value of the depreciation deduction

$k^{\prime}=$ the tax credit allowance under the Long amendment (which required firms to subtract the tax credit from their depreciation base), equal to $\bar{k}$ for the period when the Long amendment was in effect, and to zero for all other times.

\section{SPECIFICATION PROBLEMS}

Four problems arise in estimating the model, particularly with respect to the investment equation: (a) the specification of the expectations process that governs future demand and input price behavior; (b) the identification of the expectational and adjustment lags; (c) the application of the underlying production function restrictions; and (d) the presence of serial correlation among the residuals of equations (5). Each of these is a complicated issue that can be touched upon only briefly here. ${ }^{9}$

The expectations process. Expectations about future demand and prices play the central role in determining the desired level of inputs, especially those subject to adjustment costs such as capital goods. In the absence of reliable expectational data, an investigator must resort to the less satisfactory procedure of approximating expectational values of these variables from their past. There are several ways of generating the expected values of the output variable, $x^{e}$, and the price variable, $(w / c)^{e}$. In the employment and utilization equations, $x^{e}$ and $(w / c)^{e}$ are approximated by $x_{t}$ and $(w / c)_{t}$, respectively, since, for decisions that are fairly short run in nature, a current or one-period-lagged actual value is a good proxy for expected values. The expected output and relative prices in the investment equation are generated using the Almon interpolation technique. ${ }^{10}$ The choice of the degree of the polynomial and the length of the time period of the lag distribution is necessarily fairly arbitrary. Some systematic experimentation suggested a second-degree polynomial length of thirteen periods, with the far end of

9. See M. Ishaq Nadiri and Sherwin Rosen, "A Disequilibrium Model of Demand for Factors of Production" (National Bureau of Economic Research, 1972; processed).

10. Shirley Almon, "The Distributed Lag Between Capital Appropriations and Expenditures," Econometrica, Vol. 33 (January 1965), pp. 178-96. 
the distribution restricted to zero. ${ }^{11}$ The best results were obtained with polynomial distributed lags on both output and price variables, or with the polynomial lag of thirteen quarters on output and a discrete lag of relative prices. ${ }^{12}$

Expectational and adjustment lags. The expectational lags in price and output and the adjustment lags denoted by the coefficients of the dependent variables in equations (5) are interdependent. If expectations about future demand conditions are optimistic, the firm will be willing to incur higher adjustment costs; on the other hand, facing substantial adjustment costs, a firm may modify its expectations about future prices and output. Thus the estimated coefficients of lagged dependent variables $\left(\hat{\beta}_{i j}\right)$ are not completely insensitive to changes in the number of periods used to construct the polynomials on output and relative prices. However, these experiments suggested the finite lag of thirteen quarters for constructing expectational variables and an interdependent adjustment mechanism as indicated in (5).

Production function restrictions. The production function parameters are embedded in each of the equations (5) and unless the necessary restrictions are imposed, these parameters will be overidentified. ${ }^{13}$ Such restrictions are not imposed since (a) the data-especially the utilization measure - are not good enough for this purpose; (b) the aim here is an examination of the short-run determinants of aggregate investment, which does not require estimation of the full model; (c) a case can be made for estimating without restrictions and allowing the data to suggest how closely the restrictions apply. ${ }^{14}$

Serial correlation. Finally, the stochastic error term in each equation (5) is assumed to be subject to first-order serial correlation but the crosscorrelation among the residuals of different equations is assumed to be

11. The criteria for the final shape of the polynomial were that the individual distributed lag coefficients have the expected signs and be statistically significant at the 5 percent confidence level. Several periods ranging from four to twenty quarters were used to specify the lengths of the lag, and for each the degree of the polynomial was permitted to be of a different order.

12. For the results of alternative specifications of the model, see Table A-1 in Appendix A.

13. Robert M. Coen and Bert G. Hickman, "Constrained Joint Estimation of Factor Demand and Production Functions," Review of Economics and Statistics, Vol. 52 (August 1970), pp. 287-300.

14. For detailed discussion of these problems see M. Ishaq Nadiri and Sherwin Rosen, "Interrelated Factor Demand Functions," American Economic Review, Vol. 59 (September 1969), pp. 457-71. 
zero. Thus, in fitting the structural equations, all the variables are transformed by the first-order serial correlation coefficient.

\section{STRUCTURAL ESTIMATES OF THE FULL MODEL}

The structural coefficient estimates of labor and capital stock, and their rates of utilization, are shown in Table 1. The sample period is 1953:11969:4. The capital equation refers to net investment as a fraction of capital stock; that is, the dependent variable in regression equation (1) is $\Delta k_{t}$, where $k_{t}=\log \left(K_{t}\right)$. Judging from the familiar statistics $-R^{2}$, the standard error of estimate, the sum squared residuals, and $R_{c}^{2}$ (coefficient of multiple correlation in terms of changes)-the structural equations fit the data very well. This is especially true in the case of the net investment equation, which is often difficult to estimate satisfactorily. Where the variables in the stock equations are transformed for first-order serial correlation using the Cochrane-Orcutt generalized least squares technique, ${ }^{15}$ the serial correlation coefficient is reported in the last row of Table 1.

The initial effects of expected output, expected relative prices, and the time trend are indicated in the second, third, and fourth rows of Table 1. The output effect is strongest in the short run on the utilization rate and employment; it has a small but statistically significant coefficient in the hours equation. The short-run impact of expected output on investment is fairly small. The pattern of these effects suggests that when demand rises, firms increase output at first by utilizing existing capital and employment more intensively, buying time with this buffer to increase stocks. The initial impact of relative prices is statistically significant and has the right sign in both the net investment and employment equations; it is insignificant in the utilization equations. The important point is that, in both the investment and employment equations, the coefficients of relative prices (short-run price elasticities) are very small in comparison with the corresponding output coefficients. ${ }^{16}$ However, a small regression coefficient on relative prices does not necessarily imply a very small effect of prices on in-

15. D. Cochrane and G. H. Orcutt, "Application of Least Squares Regression to Relationships Containing Auto-Correlated Error Terms," Journal of the American Statistical Association, Vol. 44 (March 1949), pp. 32-61.

16. This result was repeated in each of several alternative specifications of the estimating equations that were tried, provided that output and price variables entered separately as explanatory variables. Appendix Table A-1 shows estimates for several variations of the investment equations. 
vestment in comparison with output, for the two variables are not dimensionally comparable and "typical" movements in each are not of comparable size. These effects are compared below.

The own- and cross-adjustment coefficients in each equation are shown

Table 1. Estimates of Structural Equations for Investment Expenditures by All Industries, Sample Period 1953:1-1969:4a

\begin{tabular}{|c|c|c|c|c|}
\hline \multirow[b]{2}{*}{$\begin{array}{c}\text { Independent variable } \\
\text { or statistic }\end{array}$} & \multicolumn{4}{|c|}{ Dependent variable } \\
\hline & $\begin{array}{c}\text { Net } \\
\text { investment }, \mathrm{b} \\
\Delta k_{t} \\
(I)\end{array}$ & $\begin{array}{l}\text { Utilization } \\
\text { rate, } \\
u_{t} \\
(2)\end{array}$ & $\begin{array}{c}\text { Employment, } \\
l_{t} \\
(3)\end{array}$ & $\begin{array}{c}\text { Hours } \\
\text { worked, } \\
h_{t} \\
(4)\end{array}$ \\
\hline Constant & $\begin{array}{c}-0.1707 \\
(3.357)\end{array}$ & $\begin{array}{r}-1.244 \\
(4.304)\end{array}$ & $\begin{array}{c}-5.7029 \\
(4.673)\end{array}$ & $\begin{array}{c}1.4221 \\
(6.899)\end{array}$ \\
\hline Expected output, $x_{t}^{e}$ & $\begin{array}{c}0.0580 \\
(3.412)\end{array}$ & $\begin{array}{c}0.8178 \\
(9.769)\end{array}$ & $\begin{array}{c}0.2044 \\
(4.719)\end{array}$ & $\begin{array}{l}0.0915 \\
(7.205)\end{array}$ \\
\hline $\begin{array}{l}\text { Expected relative } \\
\text { prices, }(w / c)_{t}^{e}\end{array}$ & $\begin{array}{c}0.0208 \\
(3.257)\end{array}$ & c & $\begin{array}{c}-0.0293 \\
(1.935)\end{array}$ & c \\
\hline Time trend, $T$ & $\begin{array}{c}-0.0005 \\
(4.040)\end{array}$ & $\begin{array}{c}-0.0080 \\
(7.174)\end{array}$ & $\begin{array}{c}-0.0016 \\
(4.645)\end{array}$ & $\begin{array}{r}-0.0007 \\
(5.750)\end{array}$ \\
\hline Capital stock, $k_{t-1}$ & $\begin{array}{c}-0.0676 \\
(3.477)\end{array}$ & c & $\begin{array}{c}0.3308 \\
(4.311)\end{array}$ & 0 \\
\hline $\begin{array}{l}\text { Utilization rate of } \\
\text { capital, } u_{t-1}\end{array}$ & $\circ$ & $\begin{array}{c}0.5394 \\
(5.289)\end{array}$ & c & c \\
\hline Labor stock, $l_{t-1}$ & $\begin{array}{c}0.0501 \\
(4.916)\end{array}$ & $\begin{array}{r}-0.3047 \\
(2.274)\end{array}$ & $\begin{array}{l}0.4706 \\
(8.144)\end{array}$ & $\begin{array}{c}-0.0996 \\
(8.439)\end{array}$ \\
\hline Hours worked, $h_{t-1}$ & $\circ$ & c & $\begin{array}{c}0.3015 \\
(4.208)\end{array}$ & $\begin{array}{l}0.5798 \\
(9.358)\end{array}$ \\
\hline $\begin{array}{l}R^{2} \\
R_{c}^{2 \mathrm{~d}}\end{array}$ & $\begin{array}{l}0.986 \\
0.690\end{array}$ & $\begin{array}{l}0.954 \\
0.502\end{array}$ & $\begin{array}{l}0.997 \\
0.662\end{array}$ & $\begin{array}{l}0.915 \\
0.606\end{array}$ \\
\hline $\begin{array}{l}\text { Durbin-Watson } \\
\text { statistic }\end{array}$ & 1.764 & 1.389 & 2.006 & 2.054 \\
\hline $\begin{array}{l}\text { Sum squared } \\
\text { residuals }\end{array}$ & $0.134 \times 10^{-4}$ & $40.10 \times 10^{-1}$ & $0.15 \times 10^{-2}$ & $0.10 \times 10^{-3}$ \\
\hline $\begin{array}{l}\text { Standard error of } \\
\text { estimate } \\
\text { Serial correlation }\end{array}$ & $0.477 \times 10^{-3}$ & $30.12 \times 10^{-1}$ & $0.51 \times 10^{-2}$ & $0.19 \times 10^{-2}$ \\
\hline coefficient & 0.789 & . & 0.044 & .. \\
\hline
\end{tabular}

Source: Estimates made from equations (5) discussed in the text. See Appendix B for sources of the basic data.

a. The numbers in parentheses are $t$-statistics.

b. The Almon lags for the output and relative price variables in the net investment equation are constructed as

$$
x_{i}^{i}=\sum_{i=1}^{13} \omega_{i} x_{t-i} \quad \text { and } \quad\left(\frac{w}{c}\right)^{\bullet}=\sum_{i=1}^{13} \omega_{i}^{\prime}\left(\frac{w}{c}\right)_{t-i},
$$

where the $\omega_{i}$ and $\omega_{i}^{\prime}$ are the relative weights in the Almon lags.

c. A statistically insignificant coefficient set equal to zero.

d. $R_{c}^{2}$ is the multiple correlation coefficient in terms of changes. 
by the columns of regression coefficients of lagged input variables. In equations (2), (3), and (4), the coefficients of own lagged dependent variables (for example, the coefficient of $l_{t-1}$ in the $l_{t}$ equation) are estimates of $\left(1-\beta_{i i}\right)$, while the other coefficients of lagged input variables are estimates of $-\beta_{i j}$ or the cross-adjustment parameters in each equation. In the net investment equation, (1), the coefficient of $k_{t-1}$ is an estimate of $-\beta_{22}$, the own-adjustment coefficient for the capital stock. The estimates of own-adjustment coefficients $\left(\beta_{i j}\right)$ are expected to be positive and less than unity, and that is the case in all equations, as can be calculated from the diagonal elements of the matrix of adjustment coefficients shown in rows 5 to 8 of Table 1 . The own adjustments of the utilization rate and hours worked are generally expected to be much larger-implying faster adjustments-than those of the stock variables. The estimates show that the own-adjustment coefficients of the utilization rate, hours worked, and employment are similar-about 0.5 . These coefficients are biased downward in the utilization equations due to the exclusion of relative prices and $k_{t-1}$. However, the own-adjustment coefficients of $u_{t}, h_{t}$, and $l_{t}$ stand in sharp contrast to that of capital, which is about 0.07 , indicating that the capital stock moves sluggishly and forces other inputs to adjust to satisfy demand for output in the short run.

The other component of the adjustment process is the cross-adjustment among the inputs. The common-sense interpretation of these coefficients $\left(\beta_{i j}, i \neq j\right)$ is that firms cannot fully adjust all their inputs simultaneously in the short run. A sluggish adjustment of capital stock may force the firm to increase utilization of existing capital and hire new labor. Or, if recruiting difficulties arise, the firm will intensify utilization of existing capital and perhaps plan to increase investment to reduce the costs of future labor shortages. The directions and magnitudes of these disequilibrium effects will depend on the prevailing technical and market conditions, and are difficult to predict a priori.

Each demand equation harbors significant feedback effects, though of varying magnitudes. Some of the cross-adjustment coefficients are zero and there is no clear tendency toward symmetry in their signs. The feedback effects of the capital stock on employment, utilization, and hours are shown in row $k_{t-1}$. The disequilibrium impact of capital on employment is negative $\left(\beta_{i j}<0-\right.$ that is, the regression coefficient of $k_{t-1}$ is positive in the $l_{t}$ equation). In other words, if the previous level of capital is high, employment has a tendency to increase. This suggests that the two factors rise together in the short run. In initial regressions, excess demand for capital showed insignificant effects on the utilization rate and hours worked and 
these cross-adjustment effects have been set equal to zero. ${ }^{17}$ The disequilibrium effects of employment shown by the coefficients in row $l_{t-1}$ indicate a dynamic complementarity between employment and investment and a dynamic substitutional relationship between employment and utilization rates. A bottleneck in employment checks the rate of adjustment of actual to desired capital, so that to meet heavier demand the firm must intensify the utilization of its existing resources of capital and labor. In other words, the utilization rates act as buffers in the short run. The disequilibria in hours worked and utilization rates have no significant short-run effect on the demand for capital, but an excess in hours worked does increase the demand for labor. The fact that the coefficient of the utilization rate does not enter significantly into the investment equation is somewhat disappointing. When the investment equation was estimated with $u_{t-1}$ as an additional explanatory variable, the sign of its coefficient suggested that high utilization rates do signal more investment, but not very definitely. The main problem with getting satisfactory estimates of the effect of utilization on investment is probably the inadequacy of the utilization measure used here. ${ }^{18}$

The responses of inputs to changes in expected output and relative prices differ significantly. Particularly, output elasticity of investment greatly exceeds its price elasticity, in contrast to the standard neoclassical model developed by Jorgenson and others. Also, the demand for inputs and their rates of utilization are interrelated; the stock variables, $k$ and $l$, tend to increase together, while stocks and utilization rates are substitutes for one another in the short run. Generally, the effects of disequilibria flow from stocks, especially employment, to the utilization rates. There is no significant feedback between the two utilization rates, suggesting that both may respond to a common factor such as expected output.

\section{ADJUSTMENT RESPONSE}

The distributed lag responses of the inputs to changes in output and relative prices indicated the following general pattern. Both hours worked and

17. In the utilization equation the regression coefficient of $k_{t-1}$ often turned out to be positive, which suggests a complementary relation between investment and $u_{t}$. A priori, a substitutional relation would be expected between these variables and therefore $k_{t-1}$ was excluded from the regression equation of $u_{t}$.

18. When the equation system (5) was reestimated without the utilization equation and $u_{t}$ was omitted from the remaining equations, the general properties of the estimates changed little. The interaction among the variables and the short-run price and output elasticities remained much the same. 
capital utilization respond strongly and immediately. Employment responds moderately fast. The utilization measures overshoot their equilibrium values in the first or second period and then decline to their optimum values as the stock adjustments occur. Employment gradually overshoots its long-run value and then slowly recedes to it.

The distributed lag responses of investment to a 1 percent change in output and relative prices are shown in Figures 1 and 2, respectively. These responses include both the direct effects, transmitted through the investment equation, and the indirect effects, transmitted through changes in $l_{t}, u_{t}$, and $h_{t}$ induced by the change in expected output and relative prices.

The response of investment to changes in output is "humped," similar to that reported by Jorgenson. Two features of the response pattern reported here are of interest. First, the shape of the distributed lag is obtained without imposing any a priori form on the lag structure. Second, the response of the capital stock to a unit change in output-calculated by summing the investment induced in each period-is much faster than has often been reported by other researchers. ${ }^{19}$ About 20 percent of the total response takes place in the first five quarters, contrary to Jorgenson's results. ${ }^{20}$

The pattern of investment response to a change in relative price traces an essentially geometric distributed lag and is somewhat slower than output response. This result is consistent with a "putty-clay" model of investment behavior, but does not point to it strongly.

The long-run elasticities of inputs with respect to relative prices and output could be computed from the stationary solutions of the structural equations (5) and would correspond to the relations in (3). Various experiments indicated that the structural estimates and the distributed lag patterns are relatively insensitive to the specification, but the estimates of the long-run

19. Long adjustment lags are reported by Bischoff in "Effect of Alternative Lag Distributions," and Coen and Hickman in "Constrained Joint Estimation of Factor Demand and Production Functions," p. 295. Bischoff's estimate of the time required for complete adjustment is approximately ten years, while Coen and Hickman provide an estimate of 0.16 per annum for the adjustment of capital stock. After they corrected for serial correlation in their earlier investment equations, Hall and Jorgenson, in "Application of the Theory of Optimum Capital Accumulation," reported much faster adjustment for investment in both the manufacturing and nonmanufacturing sectors. See also Dale W. Jorgenson, "Econometric Studies of Investment Behavior: A Survey," Journal of Economic Literature, Vol. 9 (December 1971), pp. 1137-39.

20. Dale W. Jorgenson and James A. Stephenson, "The Time Structure of Investment Behavior in United States Manufacturing 1947-1960," Review of Economics and Statistics, Vol. 49 (February 1967), pp. 16-27. 
Figure 1. Distributed Lag Response of Capital Stock $(\Delta \log K)$ to a 1 Percent Change in Output

Net investment as fraction of capital stock

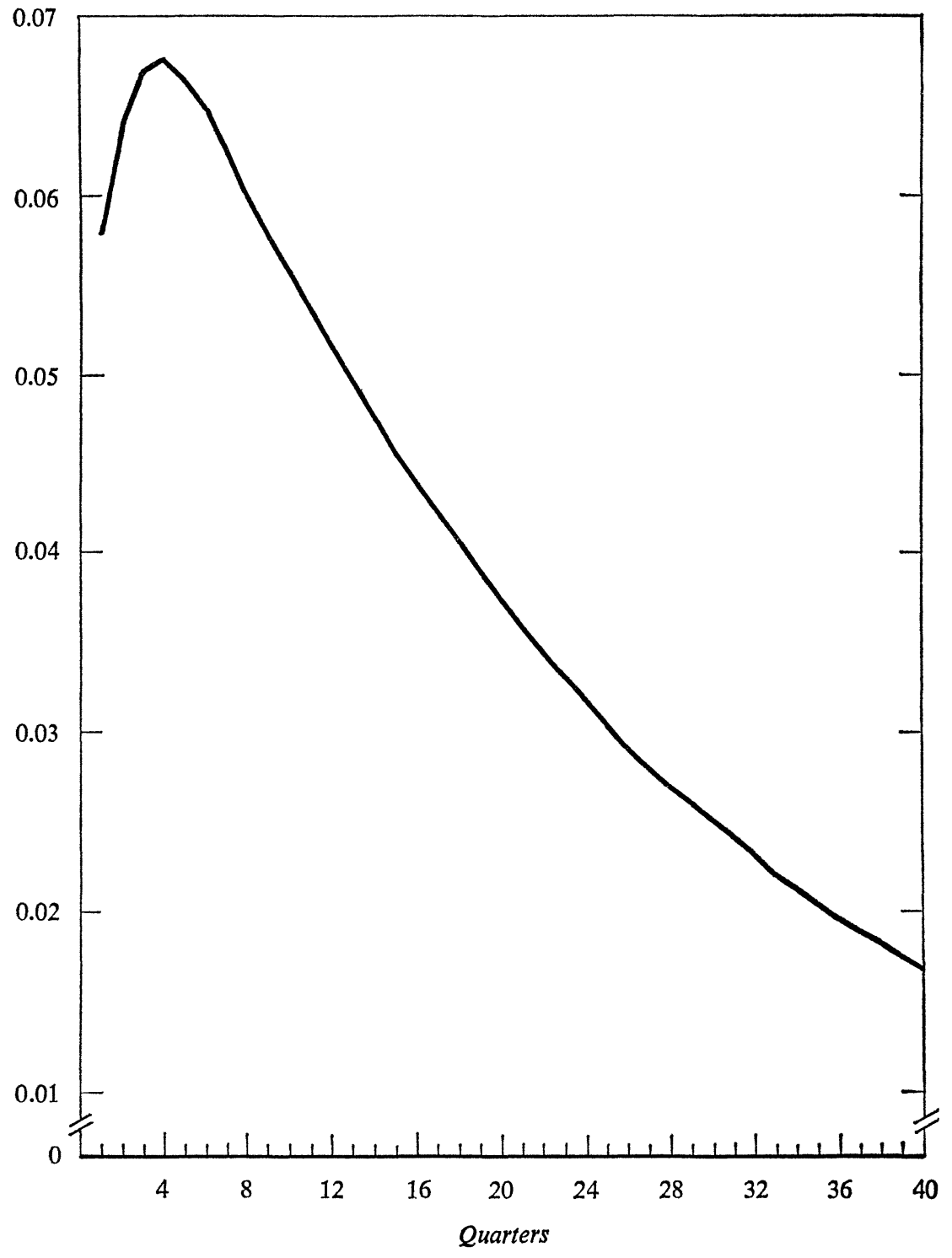

Source: Calculated from data in Table 1 by method described in text. 
Figure 2. Distributed Lag Response of Capital Stock $(\Delta \log K)$ to a 1 Percent Change in Relative Prices

Net investment as fraction of capital stock

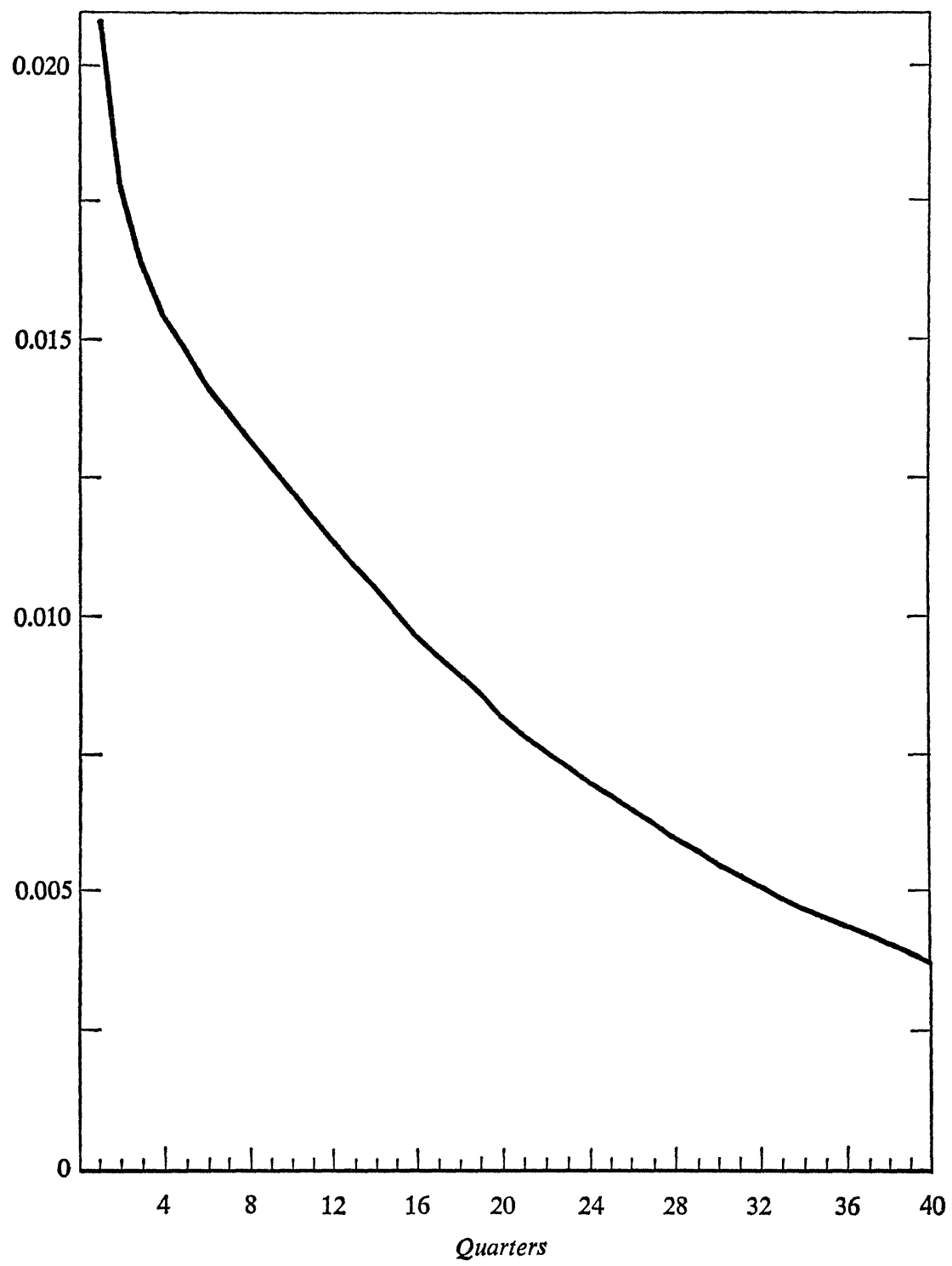

Source: See Figure 1. 
elasticities are very sensitive. Several factors may be at work: The production function constraints implicit in the structural equations are not imposed in the estimation procedure; the relevant price data are not directly available and must be constructed approximately; and, finally, small changes in the structural coefficients are magnified in the process of computing the long-run elasticities. What is important is that in every specification of the model, the long-run output elasticities were always much greater than the price elasticities. This result is in sharp contrast with the familiar neoclassical models of investment, which often combine the price and output variables into a composite variable. It argues that, in these models, the output effect dominates the combined coefficient estimate; the price effect is deduced implicitly without any independent empirical test.

\section{Prediction of Aggregate Gross Investment Expenditures}

The short-run behavior of gross investment expenditures on plant and equipment can be analyzed on the basis of the structural equations for net investment shown in Table 1. To do this requires one further step: The predicted net investment series must be converted into gross expenditures series using the relation

$$
\hat{I}=[(\operatorname{antilog} \Delta \hat{k})-1] K_{t-1}+\delta K_{t-1},
$$

where

$\hat{I}=$ the calculated gross investment expenditure

$\Delta \hat{k}=$ the predicted value of $\log \left(K_{t} / K_{t-1}\right)$

$K_{t-1}=$ the actual stock of capital at the beginning of the period

$\delta=$ the assumed depreciation rate.

In Figure 3, the actual and predicted values of aggregate gross investment for the sample period, 1953:2-1969:4, and a forecast period, 1970:11972:2, are plotted. The two periods are separated by a dashed line in Figure 3 . As can be observed, the level of gross investment in the sample period is estimated very accurately. The investment booms of 1955-57, 1959-60, and 1961-67 and the declines of investment in the recession periods since the Korean war are traced very well. The errors are small in the sample period, and rarely was more than 2.5 percent of quarterly investment overor underpredicted. The absolute mean and the root mean square of the 


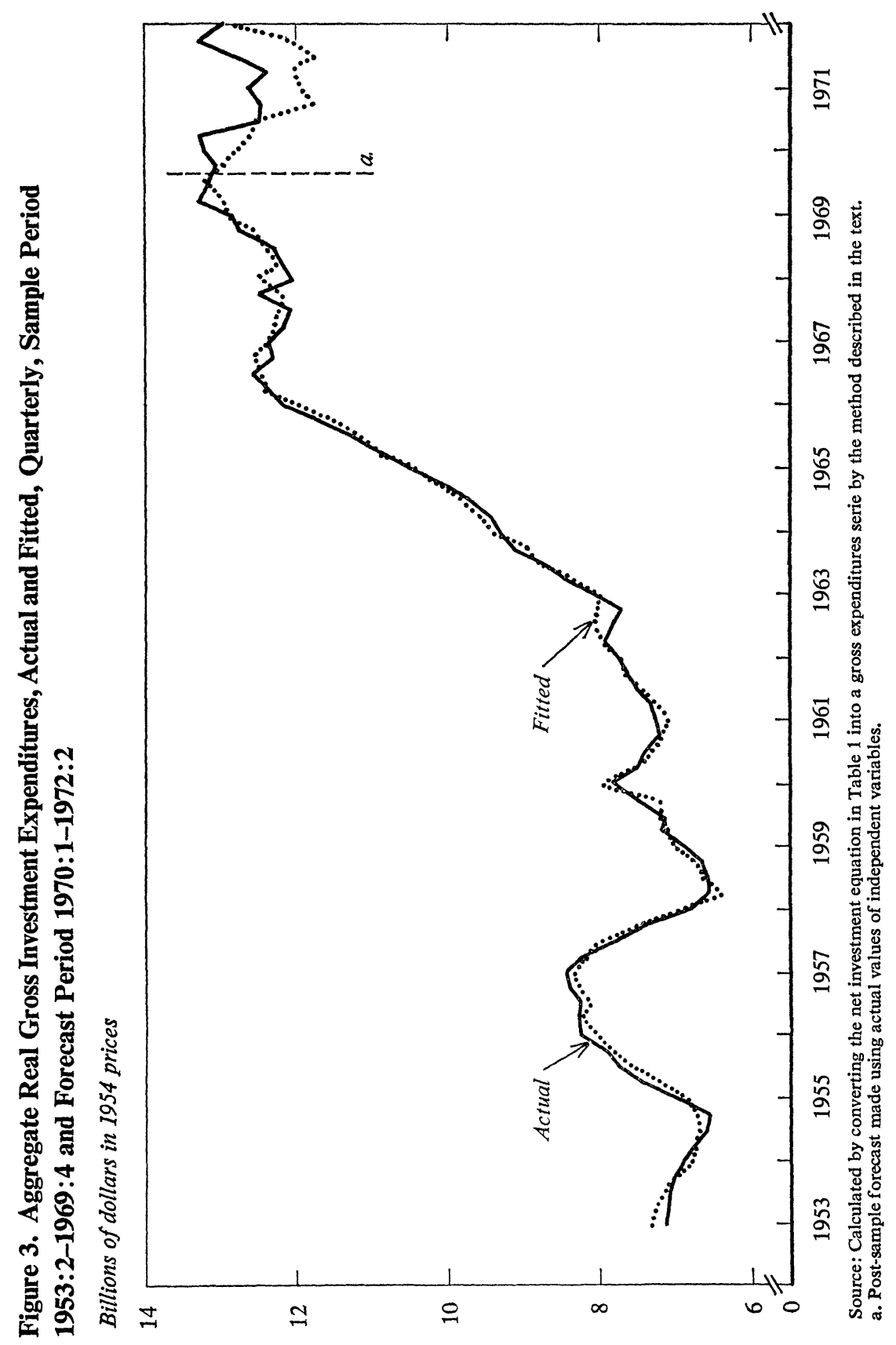


residuals were $\$ 110$ million and $\$ 145$ million, only about 1 percent of the mean value of aggregate gross investment in the period.

\section{Comparison with the Neoclassical Investment Model}

Comparison of the investment equation presented in this study with the conventional neoclassical investment models will throw light on three important issues: (a) the magnitude of the price elasticity of investment; (b) the usefulness of separating the output and relative price variables; and (c) the effects of cross-adjustment on investment decisions.

The standard neoclassical investment equation,

$$
\Delta k_{t}=a_{0}+\sum_{i}^{n} a_{i}\left[\sigma\left(\frac{p}{c}\right)+x\right]_{t-i}+b_{1} k_{t-1}+b_{2} T+\epsilon_{t}
$$

where $\sigma$ is a parameter distinguishing the impacts of prices and output, helps to answer the first question. In order to follow the usual specification of the neoclassical model more closely, the inverse of real rental price, $p / c$, where $p$ is the output deflator, is substituted for $w / c$ in equation (8). Versions of this model obtained by setting $\sigma$ equal to arbitrary values of 1.00 , $0.7,0.5,0.3$, and 0.0 were estimated with the data for the sample period 1953:1-1969:4, using the same techniques employed for estimating equation (1) of Table $1 .{ }^{21}$ The results are presented in Table 2. Standard errors decline steadily as the value of $\sigma$ is reduced from 1.0 to zero. The hypothesis of $\sigma$ equal to zero cannot be rejected at the 5 percent confidence level. These results indicate that, in this model, the price elasticity is substantially smaller than the output elasticity-indeed, is close to zero.

Table 3 presents the results for a standard neoclassical investment model modified to introduce lagged employment as an additional explanatory variable in equation (8). A comparison of each equation in Table 2 with its counterpart in Table 3 reveals plainly that, irrespective of the value assigned to the price elasticity, $\sigma$, lagged employment contributes significantly to the explanation of investment expenditures. ${ }^{22}$

21. The technique involves a second-degree polynomial lag with weights restricted to taper off to zero in the thirteenth period. The disturbance terms, $\epsilon_{t}$, are assumed to be generated by a first-order autoregressive process, and the Cochrane-Orcutt technique is used in estimating the equations.

22. The hypothesis $\sigma=1$ is clearly rejected at the 5 percent significance level but beyond that, it is hard to put confidence intervals on the value of $\sigma$. 
Table 2. Alternative Specifications of the Standard Neoclassical Investment Model, Sample Period 1953:1-1969:4a

\begin{tabular}{lccccc}
\hline & \multicolumn{5}{c}{ Equation and value of $\sigma^{\mathrm{b}}$} \\
\cline { 2 - 6 } \multicolumn{1}{c}{$\begin{array}{l}\text { Variable } \\
\text { or statistic }\end{array}$} & $(8 a)$ & $(8 b)$ & $(8 c)$ & $(8 d)$ & $(8 e)$ \\
\hline Constant & 1.0 & 0.7 & 0.5 & 0.3 & 0.0 \\
& -0.2992 & -0.3413 & 0.3641 & -0.3719 & -0.3086 \\
Time trend, $T$ & $(3.023)$ & $(3.8515)$ & $(4.338)$ & $(4.638)$ & $(3.458)$ \\
& -0.0002 & -0.0004 & -0.0005 & -0.0006 & -0.0009 \\
Composite price and out- & $(1.880)$ & $(3.173)$ & $(4.113)$ & $(4.925)$ & $(4.598)$ \\
$\quad 0.0351$ & 0.0452 & 0.0557 & 0.0729 & 0.1150 \\
put, $\left[\sigma\left(\frac{p}{c}\right)+x\right]_{t}^{\circ 0}$ & $(4.571)$ & $(4.889)$ & $(5.011)$ & $(5.170)$ & $(4.980)$ \\
Capital stock, $k_{t-1}$ & 0.0072 & 0.0065 & 0.0019 & -0.0112 & -0.0557 \\
& $(0.3649)$ & $(0.3454)$ & $(0.1026$ & $(0.5702)$ & $(2.289$ \\
$R^{2}$ & 0.968 & 0.971 & 0.9740 & 0.977 & 0.979 \\
$R_{c}^{2}$ d & 0.2859 & 0.3539 & 0.4185 & 0.4915 & 0.5349 \\
Sum squared residuals & $0.314 \times 10^{-4}$ & $0.283 \times 10^{-4}$ & $0.255 \times 10^{-4}$ & $0.223 \times 10^{-4}$ & $0.204 \times 10^{-4}$ \\
Standard error of & & & & & \\
$\quad$ estimate & $0.711 \times 10^{-3}$ & $0.676 \times 10^{-3}$ & $0.641 \times 10^{-3}$ & $0.600 \times 10^{-3}$ & $0.574 \times 10^{-3}$ \\
Serial correlation & & & & & \\
$\quad$ coefficient & 0.853 & 0.843 & 0.845 & 0.861 & 0.907 \\
Durbin-Watson statistic & 1.172 & 1.258 & 1.358 & 1.507 & 1.638 \\
\hline
\end{tabular}

Source: Estimates made for equation (8) discussed in the text. See Appendix B for sources of the basic data.

a. The numbers in parentheses are $t$-statistics.

b. In each equation the price parameter, $\sigma$, is arbitrarily set at the values indicated at the top of each column.

c. The coefficients of the composite variable $[\sigma(p / c)+x]_{t}^{6}$ are the sums of the distributed lag coefficients. d. $R_{c}^{2}$ is the multiple correlation coefficient in terms of changes.

Finally, a comparison of equation (1) in Table 1 to the equations in Tables 2 and 3 tests whether anything is gained by introducing the price and output variables separately. The hypothesis that the coefficients of the two variables should be restricted to be the same is rejected at the 5 percent significance level in each case except for equation (9e).

From these tests it is clear that the price elasticity of investment is much smaller than unity and that disequilibrium in employment is an important explanatory variable in the aggregate investment equation. They also point up the importance of separating the price and output variables in the investment equations. This practice is especially important if the effects of monetary and fiscal measures on investment expenditures are to be distinguished from the effects of the growth of output.

\section{The Effects of Monetary and Fiscal Policies on Aggregate Investment Expenditures}

Since the Korean war, several changes in fiscal policies have been aimed at influencing investment behavior. Accelerated depreciation for tax pur- 
Table 3. Alternative Specification of the Standard Neoclassical Investment Model with Lagged Employment, Sample Period 1953:1-1969:4a

\begin{tabular}{|c|c|c|c|c|c|}
\hline \multirow[b]{2}{*}{$\begin{array}{l}\text { Variable } \\
\text { or statistic }\end{array}$} & \multicolumn{5}{|c|}{ Equation and value of $\sigma^{\mathrm{b}}$} \\
\hline & $\begin{array}{r}(9 a) \\
1.0\end{array}$ & $\begin{array}{r}(9 b) \\
0.7\end{array}$ & $\begin{array}{r}(9 c) \\
0.5\end{array}$ & $\begin{array}{c}(9 d) \\
0.3\end{array}$ & $\begin{array}{r}(9 e) \\
0.0\end{array}$ \\
\hline Constant & $\begin{array}{c}-0.1556 \\
(2.497)\end{array}$ & $\begin{array}{c}-0.1603 \\
(2.555)\end{array}$ & $\begin{array}{r}-0.1632 \\
(2.584)\end{array}$ & $\begin{array}{c}-0.1660 \\
(2.562)\end{array}$ & $\begin{array}{c}-0.2102 \\
(2.286)\end{array}$ \\
\hline Time trend, $T$ & $\begin{array}{c}-0.0001 \\
(1.507)\end{array}$ & $\begin{array}{c}-0.0002 \\
(2.296)\end{array}$ & $\begin{array}{c}-0.0002 \\
(3.023)\end{array}$ & $\begin{array}{c}-0.0004 \\
(3.799)\end{array}$ & $\begin{array}{c}-0.0004 \\
(3.961)\end{array}$ \\
\hline $\begin{array}{l}\text { Composite price and out- } \\
\text { put. }[\sigma(\underline{p})+x]^{\circ}\end{array}$ & $\begin{array}{r}0.0269 \\
(5.500)\end{array}$ & $\begin{array}{r}0.0360 \\
(5.723)\end{array}$ & $\begin{array}{r}0.0458 \\
(5.891)\end{array}$ & $\begin{array}{r}0.0613 \\
(5.898)\end{array}$ & $\begin{array}{l}0.0936 \\
(4.826)\end{array}$ \\
\hline Capital stock, $k_{t-1}$ & $\begin{array}{l}-0.0477 \\
(3.353)\end{array}$ & $\begin{array}{l}-0.0537 \\
(3.528)\end{array}$ & $\begin{array}{l}-0.0606 \\
(3.721)\end{array}$ & $\begin{array}{r}-0.0716 \\
(4.0112)\end{array}$ & $\begin{array}{c}-0.0744 \\
(3.429)\end{array}$ \\
\hline Labor stock, $l_{t-1}$ & $\begin{array}{l}0.0595 \\
(7.927)\end{array}$ & $\begin{array}{c}0.0574 \\
(7.353)\end{array}$ & $\begin{array}{c}0.0554 \\
(6.720)\end{array}$ & $\begin{array}{l}0.0526 \\
(5.836)\end{array}$ & $\begin{array}{l}0.0290 \\
(2.862)\end{array}$ \\
\hline$R^{2}$ & 0.984 & 0.984 & 0.985 & 0.985 & 0.986 \\
\hline$R_{c}^{2} \mathrm{~d}$ & 0.6457 & 0.656 & 0.664 & 0.6719 & 0.689 \\
\hline Sum squared residuals & $0.156 \times 10^{-4}$ & $0.151 \times 10^{-4}$ & $0.147 \times 10^{-4}$ & $0.144 \times 10^{-4}$ & $0.137 \times 10^{-4}$ \\
\hline $\begin{array}{l}\text { Standard error of } \\
\text { estimate } \\
\text { Serial correlation }\end{array}$ & $0.505 \times 10^{-3}$ & $0.498 \times 10^{-3}$ & $0.491 \times 10^{-3}$ & $0.486 \times 10^{-3}$ & $0.474 \times 10^{-3}$ \\
\hline $\begin{array}{l}\text { Serial correlation } \\
\text { coefficient } \\
\text { Durbin-Watson statistic }\end{array}$ & $\begin{array}{c}\cdots \\
1.751\end{array}$ & $\begin{array}{l}0.809 \\
1.755\end{array}$ & $\begin{array}{l}0.812 \\
1.759\end{array}$ & $\begin{array}{l}0.824 \\
1.758\end{array}$ & $\begin{array}{l}0.856 \\
1.774\end{array}$ \\
\hline
\end{tabular}

Source: Estimates made by adding lagged employment to equation used for Table 2.

a. The numbers in parentheses are $t$-statistics.

b. In each equation the price parameter, $\sigma$, is arbitrarily set at the values indicated at the top of each column.

c. The coefficients of the composite variable $[\sigma(p / c)+x]_{t}^{e}$ are the sums of the distributed lag coefficients. d. $R_{c}^{2}$ is the multiple correlation coefficient in terms of changes.

poses was introduced in 1954; guidelines on lifetimes of depreciable assets were changed in 1962; a 7 percent tax credit for investment in equipment was introduced in the Revenue Act of 1962, and then suspended and reintroduced twice. The Federal Reserve also made important changes in monetary policy during this period in attempts sometimes to stimulate the economy and other times to restrain it. Most notably, in 1966 and again in 1969-70, the Fed pursued stringent anti-inflationary policies, which led to sharp increases in interest rates.

Several authors have reported substantial impacts of tax policy on investment, through the rental price of capital..$^{23}$ How strong these effects are depends on the price elasticity of investment and the magnitude of the change in the policy instrument. In the familiar standard neoclassical investment models, because rental price and output are usually introduced as a combined variable in the regression equation, estimates of the price elas-

23. See, for example, Hall and Jorgenson, "Application of the Theory of Optimum Capital Accumulation." 
ticity of investment are generally very high. As noted earlier, estimates of the price elasticity are fairly small in the present model.

In principle, three different effects of changes in fiscal and monetary policy measures on investment can be distinguished: (a) the most immediate, or first-period, impact; (b) the short-run effect taking account of the expectational lags on relative prices; and (c) the total effect when both expectational and structural adjustment lags are considered. The method of calculating the first two effects are similar: Multiply the change in rental prices before and after the policy change by the appropriate weights. The relevant weight for the first-period effect is the nearest coefficient of the polynomial distributed lag on rental prices. The sum of the distributed lag coefficients is the appropriate weight to obtain the short-run effects of changes in monetary and fiscal measures on investment. To calculate the overall effects (accounting for both the expectational and structural adjustment lags) of these changes, the reduced-form solution of the structural equations shown in Table 1 must be obtained. From this solution, long-run output and relative price elasticities of investment are obtained. ${ }^{24}$ Note that the distributed lag pattern of investment, as noted earlier, depends on the structural lags-that is- $\beta_{i j}$ (the coefficients of $k_{t-1}, l_{t-1}, h_{t-1}$ in Table 1); therefore, the response patterns of investment to a change in output or relative prices will be the same as those shown in Figures 1 and 2 whether the nearest coefficient or the sum of the coefficients of the polynomial distributed lag is used. The magnitude of the response will, of course, be greater when the expectational lags are allowed for. The effects of changes in fiscal and monetary measures will be even greater in the long run when the structural adjustment lags disappear and the system returns to its equilibrium position.

The focus here is on the short-run effects that allow for the expectational lags. Specifically, calculations are made of the impact effects of changes in the rate of interest, in the method of depreciation for tax purposes, and in the investment tax credit. For convenience and to illustrate the order of magnitude of the changes in net investment due to these policies, I calculate

24. The long-run elasticities and the distributed lag response of each dependent variable can be calculated by computing $[I-(I-\hat{\beta}) Z]^{-1} M . \hat{\beta}$ is the matrix of the adjustment coefficients shown in rows 5 to 8 in Table $1, Z$ is the lag operator, and $M$ is the matrix of regression coefficients, $\gamma_{i j}$, of output, relative prices, and trend shown in rows 2 and 3 of Table 1. 
different measures of rental prices by assuming various values for the interest rate and the fiscal instruments, and apply them to the data for 1968:4. ${ }^{25}$ The change in net investment is then calculated by taking the difference between net investment with the assumed change in the rental price of capital services and without it.

To calculate the effect of a change in the interest rate, suppose the nominal interest rate increases by 2 percentage points per annum. ${ }^{26}$ This significant rise is of the same order of magnitude as the actual increase in nominal interest rates between 1968 and 1970. The short-term elasticity of the rental price of capital shown in Table 1 is -0.0208 , which, when multiplied by the difference in the rental prices before and after the interest rate increase, suggests a reduction of about $\$ 0.9$ billion (in 1954 prices) in net investment. ${ }^{27}$ This amounts to a reduction of slightly more than 20 percent of actual net investment in 1968:4.

Similarly, the impact of changes in fiscal measures can be calculated as follows: The first step sets the parameters $\bar{k}$, the investment tax credit, and $z$, the discounted value of depreciation allowance in the rental price expression, equal to specific values. To calculate the impact of the change in method of depreciation, two rental prices were calculated for 1968:4, corresponding to these two depreciation methods. The reduction in rental price due to adoption of the accelerated depreciation method would have spurred an increase in net investment of about $\$ 0.6$ billion in 1968:4. Similarly, the decrease in rental price due to the presence of the investment tax credit and the Long amendment was responsible for an increase in net in-

25. The relation $\log \left[K_{t} / K_{(t-1)}\right]=\psi \log c_{i}$ can be used to estimate the impact of the policies mentioned. $\psi$ is the sum of the polynomial distributed lag coefficients on the relative price term, $(w / c)_{t}^{e}$, in the investment equation in Table $1 ; c_{i}$ refers to the estimate of rental price associated with a given value of the fiscal and monetary policy parameters.

26. I assume no changes in price expectation so that the changes in real and money rates are the same.

27. The change in net investment is calculated as:

$$
\begin{aligned}
& \log \left(\frac{K_{0}}{K_{1}}\right)=\psi\left\{\log \left[\frac{P_{k}}{1-v}\left(r_{0}+\delta\right) N_{0}\right]\right\}-\psi\left\{\log \left[\frac{P_{k}}{1-v}\left(r_{1}+\delta\right) N_{1}\right]\right\}, \\
\text { where } & \begin{aligned}
13 & w_{1}^{\prime}=-0.0208 \\
\psi & w_{i} \\
N_{0}= & \left(1-\bar{k}-v z+u z k^{\prime}\right) \\
N_{1}= & \left(1-\bar{k}-v z^{\prime}+u z^{\prime} k^{\prime}\right),
\end{aligned}
\end{aligned}
$$

and other symbols are the same as in equations (5). Note that changing the rate of interest from $r_{0}$ to $r_{1}$ also changes the discounted present value of future depreciation allowances from $z$ to $z^{\prime}$. 
vestment of approximately the same size. Finally, if all the tax parameters except for the tax rate on income were set to zero-that is, $c=\left[P_{k}(r+\delta)\right] /$ $(1-r)$-net investment would have decreased by about $\$ 3.6$ billion. By comparison with these price effects, if real output had increased by 15 percent, or $\$ 90$ billion, net investment would have increased by approximately the same magnitude- $\$ 3.1$ billion. In other words, the effect of such an increase in output on investment is equivalent to that of reducing rental prices by about 40 percent. ${ }^{28}$ The relatively small effects of changes in the rental prices on net investment is due basically to the low price elasticity of investment in the model..$^{29}$

Plainly, monetary and fiscal policy changes can have substantial influence on investment expenditures. But their effects are greatly exaggerated in the familiar standard neoclassical investment models.

\section{Forecasts of Aggregate Gross Investment}

Two types of forecast are generated using the net investment equation in Table 1. One is a conditional forecast of aggregate gross investment for the period 1970:1-1972:2, which takes the values of all independent variables at their actual values for the period. The other is a dynamic forecast for the period 1972:3-1976:4, which assumes certain exponential growth rates for the three key variables in the investment equation-lagged employment, expected prices, and expected output-and generates values of the lagged capital stock sequentially from the forecast of investment in each period.

The conditional forecasts of aggregate gross investment for the period 1970:1-1972:2 are shown in Table 4. Predicted values are quite close to actual investment; the forecast errors are generally very small, although their magnitudes increase as the forecast period lengthens. Gross invest-

28. This result is obtained by using the expression

$$
\log \left(\frac{K_{t}}{K_{t-1}}\right)=\omega_{1} \log x
$$

where $\omega=0.058$ is the short-run impact coefficient of the expected output variable, $x^{6}$.

29. The long-run effects of changes in the monetary and fiscal measures and output on net investment will be much greater than the ones noted in the text. Since the long-run elasticities are sensitive to specification errors, I have not calculated them. However, the long-run elasticity of investment with respect to output turned out in every experiment to be about three times larger than that of rental prices. Therefore, the relative ranking of the effects of a given change in output and rental price on investment will be similar to those noted in the text. 
Table 4. Conditional and Dynamic Forecasts of Aggregate Real Gross Investment Expenditures, Quarterly, 1970:1-1976:4

Billions of 1954 dollars

\begin{tabular}{rccrc}
\hline $\begin{array}{c}\text { Year and } \\
\text { quarter }\end{array}$ & $\begin{array}{c}\text { Conditional } \\
\text { forecasts }^{\mathrm{a}}\end{array}$ & Actual & $\begin{array}{c}\text { Year and } \\
\text { quarter }\end{array}$ & $\begin{array}{c}\text { Dynamic } \\
\text { forecasts }\end{array}$ \\
\hline $1970: 1$ & 12.98 & 13.06 & $1972: 3$ & 11.40 \\
2 & 12.73 & 13.22 & 4 & 11.76 \\
3 & 12.61 & 13.28 & $1973: 1$ & 12.18 \\
4 & 12.50 & 12.48 & 2 & 12.63 \\
$1971: 1$ & 11.77 & 12.47 & 3 & 13.08 \\
2 & 11.93 & 12.65 & 4 & 13.50 \\
3 & 12.00 & 12.37 & $1974: 1$ & 13.88 \\
4 & 11.75 & 12.72 & 2 & 14.23 \\
$1972: 1$ & 12.14 & 13.28 & 3 & 14.55 \\
2 & 12.76 & 12.95 & 4 & 14.85 \\
& & & $1975: 1$ & 15.12 \\
& & & 2 & 15.37 \\
& & & 3 & 15.62 \\
& & & 4 & 15.86 \\
& & & $1976: 1$ & 16.08 \\
& & & 3 & 16.31 \\
& & & 4 & 16.54 \\
\hline
\end{tabular}

Source: Derived from net investment equation in Table 1.

a. Based on actual values of the independent variables.

b. Assumes annual growth rates of 6.0 percent in output, 3.0 percent in prices, and 2.5 percent in employment.

ment is generally underestimated during this period, however; the largest absolute value of the forecast error is about $\$ 1.1$ billion (in 1954 prices) in 1972:1, about 8 percent of actual gross investment. This underprediction may reflect the effect of the resumption of the investment tax credit in 1971, the impact of which may be understated in the equation. However, for the whole ten-quarter period, the mean, absolute mean, and root mean square of the forecast errors are, respectively, $-0.531,0.535$, and 0.642 . These values are about 4 percent of gross investment in the period 1970:1-1972:2.

The dynamic forecasts shown in Table 4 are generated using the assumption that real output, relative prices, and employment will grow at annual rates of $6.0,3.0$, and 2.5 percent, respectively. The assumed exponential growth rates of output, employment, and relative prices are certainly arbitrary and unrealistic, as well as inconsistent with the spirit of the complete model, in which the level of employment is endogenous. Nonetheless, the results may be indicative of investment prospects. They suggest that gross 
investment will be lower in the latter half of 1972 than in the first half of the year. Quarterly investment expenditures increase by about $\$ 450$ million per quarter in 1973 , about $\$ 350$ million per quarter in 1974 , and more slowly thereafter.

An alternative dynamic forecast was made assuming relative prices remain constant while output and employment grow at the 6.0 percent and 2.5 percent rates per year assumed in the Table 4 projection. The levels of gross investment were, of course, smaller than those indicated in Table 4. But the difference was slight; the levels of investment were almost the same in the last two quarters of 1972 as shown in Table 4, but the difference between the two projections grew slowly in 1973 and was about $\$ 1$ billion in the last quarter of 1976.

\section{Summary and Conclusions}

The results presented in this report lead to the following conclusions:

First, the investment decision is related inherently to decisions with respect to other inputs whose adjustment it both affects and is affected by. An increase in demand is met first by increasing the utilization of existing labor and capital and then by hiring new employees and acquiring new investment goods. The dynamic decision process of changing the level and utilization of inputs constitutes a feedback system in which the disequilibrium of one input affects the adjustment process of the other.

Second, in estimates made from the present model, which separates the effects of output and relative prices on investment expenditures, changes in relative prices turn out to play a very minor role in comparison with changes in output, in both the short and long run. Compared with these results, neoclassical models that tie price and output variables together in a single variable will exaggerate the impact of monetary and fiscal policy changes. The findings here suggest that the changes in interest and tax policies that are likely in the real world will have a limited direct impact on investment expenditures.

Finally, the short-run behavior of aggregate gross investment expenditures is predicted well by the investment equation both within and beyond the sample period. The dynamic forecasts suggest that gross yearly investment will rise rapidly in both 1973 and 1974-if output grows at a constant 6 percent per year. A rise in relative prices is not likely to have an important impact on investment expenditures in the next few years. 


\section{APPENDIX A}

\section{Alternative Specifications of the Model}

TABLE A-1 PRESENTS statistical evidence further supporting the specification of the investment model developed in the text. The table shows the results of varying the specification of the investment equation in several ways.

Table A-1. Alternative Specifications of the Aggregate Investment Equation, Sample Period 1953:1-1969:4

\begin{tabular}{|c|c|c|c|c|}
\hline \multirow{2}{*}{$\begin{array}{l}\text { Independent } \\
\text { variable or } \\
\text { statistic }\end{array}$} & \multicolumn{4}{|c|}{ Equation } \\
\hline & $l^{\mathrm{b}}$ & $2^{\mathrm{c}}$ & $3^{\mathrm{d}}$ & $4^{e}$ \\
\hline Constant & $\begin{array}{c}-0.1659 \\
(2.470)\end{array}$ & $\begin{array}{c}-0.1387 \\
(2.244)\end{array}$ & $\begin{array}{c}-0.1029 \\
(1.698)\end{array}$ & $\begin{array}{c}-0.1468 \\
(1.959)\end{array}$ \\
\hline Time trend, $T$ & $\begin{array}{c}-0.0006 \\
(3.775)\end{array}$ & $\begin{array}{r}-0.0007 \\
(3.383)\end{array}$ & $\begin{array}{c}-0.0070 \\
(8.330)\end{array}$ & $\begin{array}{c}-0.0006 \\
(3.632)\end{array}$ \\
\hline $\begin{array}{l}\text { Expected wage } \\
\text { rate, } w_{t}^{e}\end{array}$ & $\ldots$ & $\begin{array}{l}0.1294 \\
(4.357)\end{array}$ & $\cdots$ & $\cdots$ \\
\hline $\begin{array}{l}\text { Expected capital } \\
\text { cost, } c_{t}^{e}\end{array}$ & $\ldots$ & $\begin{array}{r}-0.0227 \\
(3.893)\end{array}$ & $\cdots$ & $\cdots$ \\
\hline $\begin{array}{l}\text { Expected relative } \\
\text { prices, }(w / c)_{t}^{\circ}\end{array}$ & $\cdots$ & $\cdots$ & $\begin{array}{r}0.0321 \\
(4.647)\end{array}$ & $\cdots$ \\
\hline $\begin{array}{l}\text { Relative prices, } \\
(w / c)_{t-3}\end{array}$ & $\begin{array}{l}0.0055 \\
(2.127)\end{array}$ & $\ldots$ & $\cdots$ & $\cdots$ \\
\hline $\begin{array}{l}\text { Expected output, } \\
x_{t}^{e}\end{array}$ & $\begin{array}{l}0.0796 \\
(4.228)\end{array}$ & $\cdots$ & $\cdots$ & $\begin{array}{c}0.0917 \\
(4.753)\end{array}$ \\
\hline $\begin{array}{l}\text { Capital stock, } \\
k_{t-1}\end{array}$ & $\begin{array}{c}-0.0823 \\
(3.907)\end{array}$ & $\begin{array}{c}-0.0342 \\
(2.916)\end{array}$ & $\begin{array}{c}-0.0376 \\
(3.167)\end{array}$ & $\begin{array}{c}-0.0943 \\
(4.346)\end{array}$ \\
\hline $\begin{array}{l}\text { Labor stock, } \\
l_{t-1}\end{array}$ & $\begin{array}{c}0.0483 \\
(4.691)\end{array}$ & $\begin{array}{c}0.0646 \\
(8.982)\end{array}$ & $\begin{array}{c}0.0633 \\
(8.792)\end{array}$ & $\begin{array}{c}0.0471 \\
(4.457)\end{array}$ \\
\hline$R^{2}$ & 0.985 & 0.984 & 0.983 & 0.984 \\
\hline$R_{\mathrm{c}}^{2 \mathrm{f}}$ & 0.6715 & 0.6455 & 0.6237 & 0.6475 \\
\hline $\begin{array}{l}\text { Sum squared } \\
\text { residuals }\end{array}$ & $0.1442 \times 10^{-4}$ & $4 \quad 0.1556 \times 10^{-4}$ & $0.1636 \times 10^{-4}$ & $4 \quad 0.1547 \times 10^{-4}$ \\
\hline $\begin{array}{l}\text { Standard error of } \\
\text { estimate } \\
\text { Serial correlation }\end{array}$ & $0.4903 \times 10^{-3}$ & $30.505 \times 10^{-3}$ & $0.5137 \times 10^{-3}$ & $30.5037 \times 10^{-3}$ \\
\hline $\begin{array}{l}\text { coefficient } \\
\text { Durbin-Watson }\end{array}$ & 0.8567 & 0.858 & 0.941 & 0.878 \\
\hline statistic & 1.679 & 2.0135 & 1.820 & 1.642 \\
\hline
\end{tabular}

Source: Derived from equations (5) discussed in the text. See Appendix B for sources of the basic data. a. The numbers in parentheses are $t$-statistics.

b. Discrete lag for relative price term (that is, $(w / c)_{t-3}$ ) with $x_{i}^{i}$ of thirteen quarters and near end open.

c. Relative prices are entered separately with no output variables.

d. No output variable but prices entered as $(w / c)$.

e. Expected output and time trend but no relative price term.

f. $\boldsymbol{R}_{\mathrm{c}}^{2}$ is the multiple correlation coefficient in terms of change. 
APPENDIX B

\section{Sources of Data and Method of Constructing the Variables}

THE DATA used in this analysis are quarterly time series on capital stocks, the rate of capacity utilization, total employment, hours worked, wage rates, and the rental price of capital and output for the period 1947:11972:2.

The major sources of the data are (a) U.S. Office of Business Economics, The National Income and Product Accounts of the United States, 1929-1965: Statistical Tables (1966); (b) various issues of Survey of Current Business; (c) U.S. Bureau of Labor Statistics, Employment and Earnings, United States, 1909-70, Bulletin 1312-7, and various monthly issues of Employment and Earnings. Other sources are noted where applicable.

\section{Capital Stock and Investment Series}

The investment series refers to private nonfarm investment expenditures on plant and equipment. The Office of Business Economics-Securities and Exchange Commission quarterly survey of gross investment expenditures on new plant and equipment were adjusted and deflated by the gross national product (GNP) implicit deflator for nonresidential nonfarm fixed investment, with $1954=100$. Benchmark estimates of net capital stock (in 1954 prices) for the end of 1946 were taken from Bert G. Hickman, Investment Demand and U.S. Economic Growth (Brookings Institution, 1965), p. 230. The capital stock series was calculated from $1947: 1$ using the relation $K_{t}=I_{t}+(1-\delta) K_{t-1}$, where $K_{t}$ is the real stock of capital at the end of period $t ; I_{t}$ is the rate of real gross investment in period $t$; and $\delta$ is the quarterly rate of depreciation. The value assigned to $\delta$ is 0.022 , calculated as a weighted average of the depreciation rates for equipment and structures reported by Robert E. Hall and Dale W. Jorgenson in "Application of the Theory of Optimum Capital Accumulation," in Gary Fromm (ed.), Tax Incentives and Capital Spending (Brookings Institution, 1971), pp. 9-60. 


\section{Output Series}

The output series refers to quarterly data on income originating by all industries, reported in The National Income and Product Accounts. The data are seasonally adjusted and are at annual rates. The series is deflated by the implicit price deflator for GNP.

\section{Calculation of Rental Prices}

The rental price of capital was calculated by using the formula,

$$
C=\frac{P_{k}(\bar{r}+\delta)\left(1-\bar{k}-v z+v z k^{\prime}\right)}{(1-v)},
$$

where

$P_{k}=$ the price of investment goods

$\bar{r}=$ the real rate of interest, calculated as $\bar{r}=r-(\dot{p} / p)^{e}$, where $r$ is the nominal quarterly rate of interest on Moody's Aaa industrial bonds and $(\dot{p} / p)^{e}$ is a measure of expected inflation calculated as a weighted average of change in the consumer price index. The weights are taken from Robert J. Gordon, "Inflation in Recession and Recovery," Brookings Papers on Economic Activity (1:1971), Table A-1, p. 148.

$\delta=$ the rate of quarterly depreciation

$\bar{k}=$ the effective rate of the investment credit

$k^{\prime}=$ the tax credit allowance under the Long amendment, which required firms to subtract their total tax credit from their depreciation base. It is equal to $\bar{k}$ during the time when the Long amendment was in effect and 0 all other times.

$v=$ the corporate income tax rate

$z=$ the present value of the depreciation deduction.

\section{PRESENT VALUE OF DEPRECIATION}

The present value of the depreciation deduction, $z$, takes into account the liberalization of depreciation allowances in 1954 and the decline in the average life of capital that appears to have occurred in most American in- 
dustries. I have assumed, following Bischoff, a straight-line method (SL) from 1947 to 1954 and a weighted average of the sum-of-the-years-digits (SYD) and the straight-line methods from 1954 to the present. ${ }^{1}$ The weights used were $\omega(S Y D)+(1-\omega) S L$, where $\omega=0.524$, estimated by Bischoff. The formulas employed to calculate $z$ were (a) the straight-line method:

$$
z_{s l}=\left(1-e^{-r T}\right) /(r T) ;
$$

and (b) the sum-of-the-years-digits method:

$$
z_{s y d}=\left[\frac{2}{(r T)}\right]\left[\left(1-e^{-r T}\right) /(r T)\right],
$$

where $T$ is the lifetime of the asset for tax purposes.

ESTIMATES OF LIFE OF CAPITAL

I have used the following estimates of capital life based on Hall-Jorgenson figures for equipment and structures for total manufacturing and nonfarm nonmanufacturing: ${ }^{2}$

\begin{tabular}{lc}
\multicolumn{1}{c}{ Period } & $\begin{array}{c}\text { Asset lifetime } \\
\text { (quarters) }\end{array}$ \\
$1947-54$ & 80 \\
1955 & 76 \\
$1956-61$ & 72 \\
$1962-1971$ & 64
\end{tabular}

\section{TAX CREDIT}

The 7 percent investment credit for "qualified" investment expenditures was enacted as part of the Revenue Act of 1962, which became law on October 16, 1962. Initially, the amount of investment credit was deducted from the depreciable basis of the property, but this provision (the Long amendment) was repealed by the Revenue Act of 1964, signed into law

1. The rationale is that although depreciation guidelines were liberalized, many firms continued to calculate depreciation deductions for tax purposes using the straight-line method. Although the evidence is by no means sufficient, I have accepted Bischoff's calculations, which appear to be plausible, judging by the available information. For further discussion, see Charles W. Bischoff, "The Effect of Alternative Lag Distributions," in Fromm (ed.), Tax Incentives, pp. 83-85.

2. "Application of the Theory of Optimum Capital Accumulation," p. 31. 
February 26, 1964. The investment credit provisions were suspended in October 1966. The suspension was terminated March 9, 1967.

The Tax Reform Act of 1969 repealed the investment credit with respect to property placed in service after April 18, 1969, whose purchase was not subject to a binding contract in effect before that date. The tax credit was reenacted effective August 15, 1971, as part of the President's new economic policy.

Bischoff has argued that the effective tax credit in 1963 was 5.5 percent, in comparison with the legal rate of 7.0 percent. His reasons are that 90 percent of equipment purchased was eligible for the credit and that 20 percent of equipment purchases were made by public utilities, which were allowed only a 3 percent credit. I have taken Bischoff's estimate as a first approximation to the true tax credit rate.

\section{Employment, Hours, and Wage Series}

Employment is measured by total employees on private nonagricultural payrolls; hours refer to average weekly gross hours per production worker on private nonagricultural payrolls; and wages are the average gross hourly earnings of production workers in total manufacturing. The employment and wage data are taken from U.S. Bureau of Labor Statistics, Employment and Earnings, United States, 1909-70, Bulletin 1312-7. Revised figures for 1968-70 and data for 1971 were obtained from monthly issues of Employment and Earnings. All monthly data are seasonally adjusted and averaged to quarterly figures.

\section{Utilization Rates}

The difficulties of measuring hours worked by capital and the intensity with which it is used during those hours are well known. As noted in the text, my measure of utilization is actually an output variable. It refers essentially to a generalized measure depicting the underutilization of all inputs, including capital stock. In the absence of any satisfactory measure, I have used a weighted index of the Wharton capacity series. ${ }^{3}$

3. L. R. Klein and R. S. Preston, "Some New Results in the Measurement of Capacity Utilization," American Economic Review, Vol. 57 (March 1967), pp. 34-58. 


\section{Comments and Discussion}

Franco Modigliani: This paper offers an ingenious formulation of the investment demand process. However, I feel that to exploit it, several features of Nadiri's model need further attention. The original feature of the underlying production function is the separate introduction of capital and labor utilization. This formulation implies that, for a given stock of capital, a given output can be produced with various combinations of capital utilization and labor. However, whether this formulation is meaningful depends on whether one sees the world as approximated by a putty-clay model of capital, in which the way labor works with capital is determined when investments are made; or a putty-putty model, in which labor and capital can be substituted freely even after capital is in place. If the putty-clay model is the better approximation, Nadiri's formulation gives a meaningful ex ante production function but not an ex post one. Once the amount of capital is fixed, the utilization of capital and the input of labor cannot be independently varied. This problem is serious because the equations describing the conditions for short-term adjustment assumed that such variations can be made. For example, the partial derivative of output with respect to the utilization of capacity is calculated holding the utilization of labor constant.

I also have trouble with the labor cost concept Nadiri uses. Total cost includes labor in two ways. The first is a conventional variable cost, calculated as the wage rate times employment times the average number of hours worked. The second is a partially fixed cost, calculated as a cost per unit times the level of employment. While such partially fixed costs are more important in some other countries, I believe they are very unimportant in the United States.

A final problem with Nadiri's formulation arises in equation set (3), which gives the optimum values of the four inputs as functions of output 
and relative prices. The rate of change of depreciation with respect to output appears in the denominator of three of the four expressions; yet that rate of change can certainly be zero, or close to it. Because no constraint has been placed on how intensely capacity can be utilized and no special costs have been introduced that may actually be associated with using it more intensely, the equations formulated here tell us to expand capital utilization indefinitely since this, by assumption, produces additional output without additional cost.

I would have preferred a measure of the cost of capital that made use of stock prices. I and others have used the dividend-price ratio for this purpose. Earnings fluctuate too much, while in a world in which firms tend to stabilize dividends on the basis of expected profits, dividends offer a measure of expected earnings. Of course, there is error in this measure, just as there is in attempting to calculate real interest rates from nominal rates, or in assuming that the risk premium that investors require is constant over time. When both measures have errors, the appropriate procedure is to use an average of the two-either with predetermined weights or with weights chosen by regression. In work I and others have done, we have come up with about 60 percent of the weight on the rate of interest and 40 percent on the dividend-price ratio.

R. J. Gordon: I see two major issues discussed in this paper. The first one is the important concern for policy makers. Monetary and fiscal policy affect investment directly through the price of capital services. So the crucial question is, What is the elasticity of the desired stock of capital to a change in the price of capital services? In answering this question for, say, the investment tax credit, it is important to specify the assumptions made about monetary policy. If the effect of the tax credit is estimated with the money supply held constant, the stimulus to investment from the credit will raise interest rates and thus offset some of the expansionary effect. If, on the other hand, the effect is estimated holding interest rates constant, the stimulus from the investment tax credit will lead the Federal Reserve to expand the money supply. So monetary policy has to be carefully specified in evaluating tax credit changes. This done, the answer depends on the elasticity of investment to the price of capital services. The effectiveness of the tax credit and other policy measures has been debated for six or seven years now, and one question is whether this paper takes us any further than the conference held in Brookings in 1967. 
The second issue is the introduction in this paper of interrelations among factor demand functions. Does the actual capital stock adjust more rapidly to a given desired level when labor markets are tight or when they are easy? While this question is not directly of great policy importance, it is important for our understanding of the way the investment process works.

What has the paper contributed to these two issues? First, the evidence presented is not at all persuasive that the price elasticity of investment is much smaller than unity. We can see this in several places. In Table 3, showing alternative specifications of the investment equation, all equations are similar in including the interrelated labor term, but they differ in constraining the elasticity with respect to the price of capital services. The standard errors are not far apart. Consequently, it is not at all clear that the elasticity is less than 1.0 , because the data are inadequate to discriminate among the equations. Appendix Table A-1 again reveals only a very small change in the standard errors as the equation specification is changed. I cannot help but draw the analogy between the difficulty of estimating the price effect here and the difficulty of estimating the coefficient of past inflation in a wage equation, a problem I have wrestled with for several years. Nadiri has my sympathy; but I think he should admit how uncertain the estimate of the correct coefficient is in his results. Perhaps we will have to be patient and wait for ten more years of data before we can say anything very conclusive about them. Certainly nothing in this paper leads me to conclude that the elasticity is either high or low.

Figure 3 shows that most of the variance of investment took place between 1963 and 1966. How that very rapid rise is explained will affect the results significantly. Two things were happening during that period: Output was growing very rapidly and the price of capital services was dropping in response to the investment tax credit. Therefore, the difficulty in distinguishing statistically the relative importance of each of these factors in explaining investment is not surprising.

Second, a comparison of Tables 2 and 3 shows that the lagged employment term really matters. With relative prices, lagged capital stock, and expected output constant, the equations tell us that an increase in employment encourages investment; failure to increase employment restrains investment. Nadiri interprets this as a labor bottleneck effect. But other interpretations are possible. In economics we usually have to estimate expected values of variables on the basis of their past values. But it may be that the hiring of labor is a better measure of expected output than is past output it- 
self. For instance, a big investment boom developed in 1968 and 1969. At the same time, a puzzling dropoff occurred in productivity as firms hired an extraordinary number of workers for the output growth that took place. If we interpret this extensive hiring as a reflection of confidence, it becomes an indicator of good business expectations and, as such, helps explain the investment rise of that period. That seems a plausible interpretation, and it does not rest on the concept that labor bottlenecks influence investment. It is an alternative way in which labor input may play a role in these equations.

Finally, Feldstein and Foot have recently written a paper demonstrating a systematic cyclical pattern in replacement investment. ${ }^{1}$ Investment equations, such as those developed here, should take this into account rather than simply explaining net investment.

\section{General Discussion}

Saul Hymans pointed out that 1968 and 1969 were good years for investigating the effects on investment of labor bottlenecks; thus they could not be used to distinguish a bottleneck effect from the expectations effect that R. J. Gordon had proposed. He also disagreed with Modigliani about the importance of fixed labor costs in the United States, arguing that they were important and that firms made substantially different decisions about expanding the variable and overhead components of their employment. He noted that automobile output had increased enormously in recent years without a corresponding employment increase because automobile firms have not wanted to incur additional fixed costs without being certain that the additional workers would be needed over a long period of time.

Several discussants were concerned about the inability of the model to produce sensible long-run elasticities of the capital stock with respect to output. Robert Hall noted that this difficulty frequently arose with investment demand models when the a priori restrictions of the neoclassical formulation were relaxed. He did not know what confidence to place in short-run characteristics estimated by the model when these estimates implied a violation of sensible long-run characteristics such as the eventual doubling of capital stock if output were doubled. Nadiri responded that

१. Martin S. Feldstein and David K. Foot, "The Other Half of Gross Investment: Replacement and Modernization Expenditures," Review of Economics and Statistics, Vol. 53 (February 1971), pp. 49-58. 
these long-run characteristics were extremely sensitive to small changes in the specification of the model and that with some restrictions on his specification, he could get sensible long-run elasticities; but that to discover shortrun impacts and interactions, it was best not to impose such restrictions. In this connection, Modigliani seconded R. J. Gordon's suggestion that the model be formulated to explain gross rather than net investment. He reported that in his own work, the use of gross investment avoided many pitfalls that were encountered in trying to explain net investment econometrically, and specifically resulted in the reasonable estimates of the long-run elasticities of investment and capital stock that Nadiri had been unable to get with his model.

Some discussants were skeptical of the role played by the capital utilization variable in the model. William Nordhaus felt that this variable had little to do with utilization but rather simply measured output adjusted by a trend. Arthur Okun agreed that the variable did not measure utilization and found it hard to interpret the empirical result that a given output could be produced by substituting labor for utilization as measured here.

Charles Holt suggested two directions in which the model might be usefully expanded: First, as it stands, the model is premised on minimizing costs taking production as given. But other considerations, such as pricing in a noncompetitive setting and inventory policy, are important in modeling a firm's decision making in the face of a shift in demand. These considerations should be included and the model solved so as to maximize profits. Second, more theoretical specifications should be placed on the lags in the adjustment process. For most business investments, a lead time exists between placing capital goods orders and getting investment in place, and this lead time can be expected to vary cyclically. It would be interesting to see how estimates from the model would change if restrictions were imposed to allow for this kind of lag pattern rather than relying on unrestricted estimates that simply gave the best average fit to the data. 